\title{
The Effect of the Addition of Bentonite Clay to Traditional Sand Mixtures on the Surface Quality of Iron Castings
}

\author{
Jadwiga Kamińska'", Sabina Puzio' ${ }^{1}$, Michał Angrecki', Mateusz Stachowicz² \\ 1 ŁUKASIEWICZ - Foundry Research Institute, Department of Technology, Zakopianska 73, 30-418 Cracow, \\ Poland \\ 2 Wrocław University of Technology, Faculty of Mechanical Engineering, Chair of Foundry Engineering, Plastics \\ and Automation, Ignacego Łukasiewicza 5, 50-371 Wrocław, Poland \\ * Corresponding author's e-mail: jadwiga.kaminska@iod.krakow.pl
}

\begin{abstract}
Successful casting demands that during pouring of the foundry mould with molten metal the mould cavity suffers no deformation. This, in turn, demands the use of binding materials that can give the base sand adequate strength. The main bonding materials are clay binders. The foundry industry uses minerals rich in clay, such as kaolinite, halloysite, hydromica, montmorillonite, polygorskite, vermiculite and allophane. Due to their binding capacity, montmorillonites are the most interesting minerals of all the plastic clay rocks. The basic clay rock containing montmorillonite, used as a common binding material for traditional foundry sand mixtures, is bentonite. The domestic demand for raw bentonite materials is almost entirely satisfied by imports from Slovakia, Turkey, Italy, Germany and the Czech Republic, in order of import size. In Poland, the bentonite deposits occur in very small quantities. The exploitation of bentonites is carried out only in the Krzeniów deposit, where they constitute a mineral accompanying basalt. Much more common are bentonite clays containing in addition to smectites also a large amount of other clay minerals. The article presents the results of studies of the physico-chemical and mechanical properties of moulding sand mixtures containing pure bentonite, pure clay or hybrid bentonites which are a bentonite-clay mixture. Melting was also carried out to determine the effect of the type of binder on the surface quality of iron castings.
\end{abstract}

Keywords: bentonite; bentonite clay; traditional sand mixtures; casting surface quality

\section{INTRODUCTION}

The current pro-ecological policy of the European Union (the directive on industrial emissions known as a "new IPPC") forces foundries to use materials that show the least harmfulness to the natural environment [Dańko et al. 2010]. The use of technologies based on chemically bonding materials, organic binders - in particular, is being limited due to possible threats they can create to both employees and the environment, and difficulties associated with the reclamation and utilization of waste moulding materials [Kowalski 2011]. For ecological and economic reasons, foundries are increasingly using traditional moulding sands with clay binders, primarily with bentonite. Statistical data shows that over $75 \%$ of the world's production of iron alloy castings is made in traditional moulding sands with bentonite [Beňo et al. 2016 Lee et al. 2004; Aramide et al. 2011].

The main problem in the manufacture of castings from various alloys is obtaining the best surface quality. Casting demands that during pouring of mould with molten metal, the mould cavity suffers no deformation. This, in turn, demands the use of binding materials capable of conferring sufficient strength to the moulding sand [Miksovsky et al. 2008; Priyadharsini et al. 2016].

Surface quality of castings made in bentonitebonded moulding sands depends on the quality of the raw material from which the foundry bentonite is processed [Stefański et al. 2010; Vasková et al. 2012]. In Poland, bentonite deposits are found in very small quantities. Much more common are 
bentonite clays containing, besides smectites, a large amount of other clay minerals [Brzeziński 2018]. Out of concern for the environment and rational management of raw materials, the ŁUKASIEWICZ - Foundry Research Institute has been implementing an innovative idea of using domestic bentonite clays to make full-value materials for the foundry industry.

The aim of the studies was to answer the questions how the increasing clay content in hybrid bentonites can affect the mechanical and technological properties of traditional moulding sand mixtures and change the structure of the casting surface layer.

\section{MATERIALS AND METHODS}

Tests were carried out on two raw minerals, i.e. bentonite clay called beidellite from the Turoszów Mine overburden deposits and foundry bentonite from one of the Slovak deposits. Both materials were subjected to a two-stage activation process, initial drying and milling to obtain the appropriate granulation in accordance with $\mathrm{PN}-85 / \mathrm{H}-11003$.

The activation of clay and bentonite lasted 30 days, which is similar to the process applied by Polish producers of bentonite, as this is the period of time that allows sodium ions to substitite calcium ions. The process of bentonite activation is carried out to improve the bentonite properties important for the casting process. Compared to minerals before activation, sodium-activated bentonite and clay are characterized by increased binding capacity due to a higher content of montmorillonite. The activation process also leads to the extension of 2:1 sheet units characteristic of the smectite group of minerals.

The above mentioned raw materials were used as components of hybrid bentonites containing $10,15,20$ and $30 \%$ of clay in their composition. The rest was bentonite.

As part of the physico-chemical studies, parameters most important for the casting process, i.e. montmorillonite content and swelling index, were determined. Montmorillonite content was determined by spectrophotometric method of $\mathrm{Cu}$ (II) - triethylenetetramine (Cu-TET) copper complex. The $\mathrm{Cu}$ (II) - triethylenetetramine complex method involves the adsorption of a copper complex on montmorillonite particles contained in bentonite. The measurement is made at a wavelength of 620 $\mathrm{nm}$. The result is the consumption of the $\mathrm{Cu}$-TET complex expressed in $\mathrm{mmol} / \mathrm{l}$ and converted to the cation exchange capacity expressed in percent. As a blank material, distilled water is used. The swelling index was determined in accordance with PN$85 / \mathrm{H}-11003$. The measurement consisted in introducing $2 \mathrm{~g}$ portions of bentonite into a measuring cylinder with $100 \mathrm{~cm} 3$ of distilled water. After the entire amount of bentonite had been introduced, the sample was allowed to stand for 2 hours and then the volume of precipitate deposited at the bottom of the cylinder was read.

In the next stage of the research, traditional moulding sands containing 9 parts by weight of bentonite, clay or hybrid bentonite were prepared in an LM-1 laboratory edge runner mixer. Then the main mechanical and technological properties of the prepared sand mixtures were determined.

Melting was also carried out to determine the effect of clay content in hybrid bentonite on the external surface quality of iron castings. For reconstruction of the casting surface, a HITACHI scanning electron microscope (SEM), model TM-3000, and dedicated graphical and analytical software were used.

\section{RESULTS}

\section{Physico-chemical tests}

Table 1 summarizes the basic properties of bentonite, clay and hybrid bentonites. Prepared hybrid bentonites are a mixture of bentonite and bentonite clay with a variable percentage of clay $(10,15,20$ and $30 \%$ clay). In further part of the research work they are designated as 90/10, $85 / 15,80 / 20$ and $70 / 30$, respectively.

Compared to clay, bentonite is characterized by a much higher content of montmorillonite (higher by over $35 \%$ ). Increasing the clay content in hybrid bentonite causes gradual decrease in the swelling index. Unfortunately, this is an unfavourable feature, as it reduces the bentonite ability to swell freely, i.e. to absorb water between sheet units.

\section{Permeability}

To obtain sound castings, gases formed during pouring of liquid metal must be vented outside the mould. The sand mixture ability to remove gases is determined by a technological property called permeability. 
Table 1. Basic physical and chemical properties of the tested minerals

\begin{tabular}{|c|c|c|c|c|c|c|}
\hline \multirow{2}{*}{ Parameters } & \multicolumn{5}{|c|}{ Clay content in moulding sand, \% } \\
\cline { 2 - 7 } & $\begin{array}{c}0 \text { (pure } \\
\text { bentonite) }\end{array}$ & $10(90 / 10)$ & $15(85 / 15)$ & $20(80 / 20)$ & $30(70 / 30)$ & 100 (pure clay) \\
\hline Montmorillonite content, \% & 87.3 & 79.3 & 78.7 & 75.6 & 74.0 & 56.8 \\
\hline Swelling index, ml/2 g & 38 & 25 & 24 & 23 & 19 & 6 \\
\hline
\end{tabular}

Permeability was measured on standard cylindrical $\varnothing 50 \times 50 \mathrm{~mm}$ specimens using an LPiR-3e apparatus. An increase in sand moisture content caused a decrease in permeability (Fig. 1). Moulding sands based on pure bentonite were characterized by the lowest permeability in the entire tested range of moisture content values. Moulding sands containing other clay binders had comparable permeability values.

\section{Compressive strength}

Green compressive strength was measured on standard cylindrical specimens using a universal $\mathrm{LRu}-2 \mathrm{e}$ type strength measuring apparatus. In the examined range of moisture content values, the green compressive strength of sand mixtures was decreasing with increasing moisture content (Fig. 2). An increase in moisture content from 2.5 to $3.0 \%$ had only a negligible effect on the strength decrease (about 4\%). With further increase in moisture content, the decrease in strength was much more significant, amounting to $15 \%$ for a moisture content of $3.5 \%$ and to over $30 \%$ for a moisture content of $4.0 \%$. The sand mixture based on $80 / 20$ hybrid bentonite obtained the highest value of compressive strength, i.e. over $0.15 \mathrm{MPa}$ at a moisture content of $2.5 \%$.

\section{Tensile strength in the transformation zone}

Tensile strength in the transformation zone was measured in a special laterally divided sleeve using an LRP device. The principle of the test consisted in heating the base of a cylindrical specimen to $310^{\circ} \mathrm{C}$ for $20 \mathrm{~s}$, which caused water evaporation and movement of water vapour inside the sand mixture. This parameter can be an indicator of the formation of surface defects in castings, such as scabs, veins and rattails. With moisture content increasing in the sand mixture, the tensile strength in the transformation zone was also increasing (Fig. 3). For all the tested moisture content values, the sand mixture based on $80 / 20$ hybrid bentonite showed the highest strength values. The maximum of $654 \mathrm{~N} / \mathrm{cm}^{2}$ was observed at a moisture content of $4.0 \%$.

\section{Friability}

The sand particles in synthetic moulding sands are characterized by a strong tendency to detach from the specimen surface, which means high friability. The measurement consisted in rubbing the compacted cylindrical specimen against the rolls of an LS apparatus for a period of 5 minutes. During measurement, the specimen was heated with an irradiation lamp to a temperature of $95 \pm 3^{\circ} \mathrm{C}$.

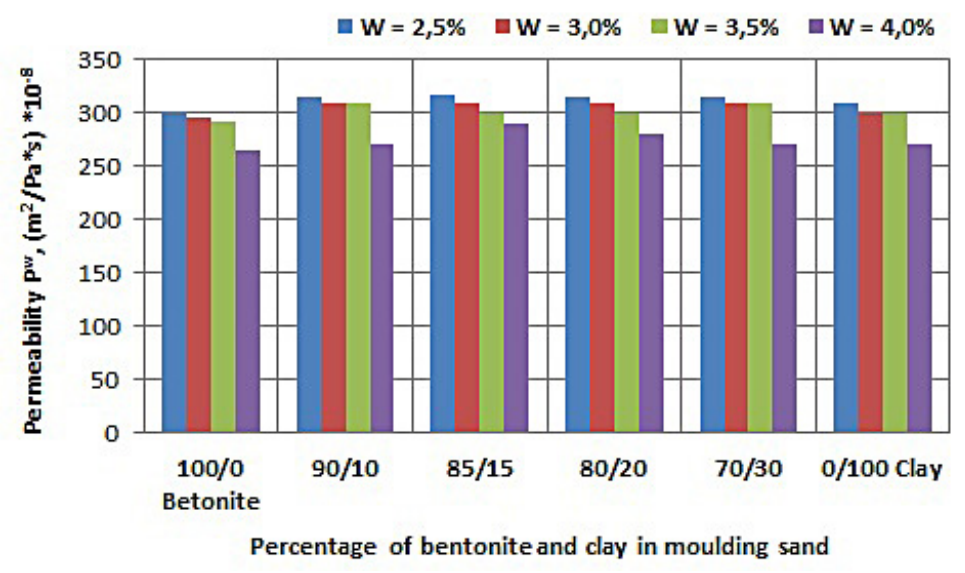

Fig. 1. The effect of clay content on the permeability $\mathrm{P}^{\mathrm{w}}$ of the tested sand mixtures 


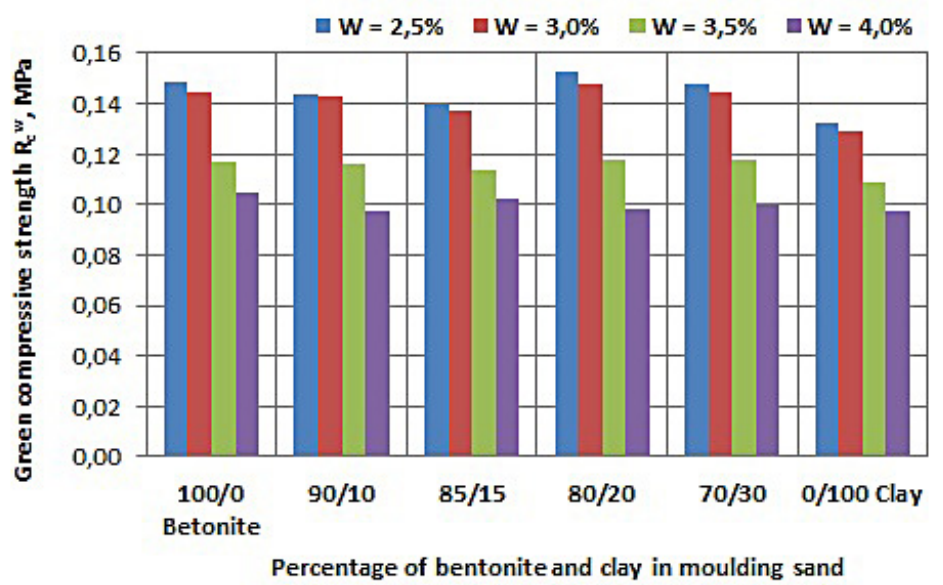

Fig. 2. The effect of clay content on the green compressive strength $\mathrm{R}_{\mathrm{c}}{ }^{\mathrm{w}}$ of the tested sand mixtures

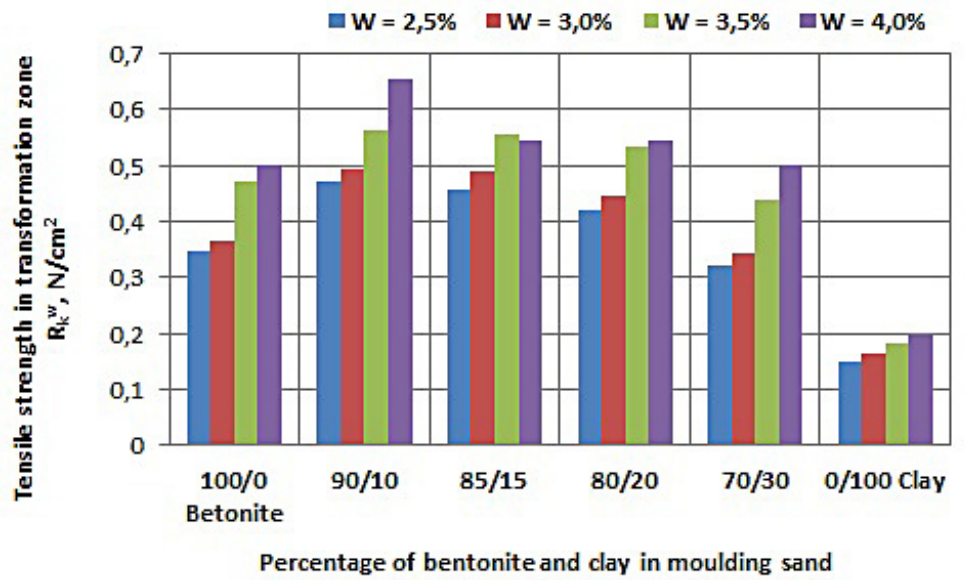

Fig. 3. The effect of clay content on the tensile strength in the transformation zone $\mathrm{R}_{\mathrm{k}}{ }^{\mathrm{w}}$ of the tested sand mixtures

With decreasing moisture content, the friability index was increasing (Fig. 4), mainly due to faster drying of the specimen surface. High clay content in hybrid bentonites causes gradual increase in sand friability.

\section{Casting surface quality}

For reconstruction of the surface of iron castings, a HITACHI scanning electron microscope (SEM), model TM-3000, and dedicated graphical and analytical software were used.

Prior to roughness measurement, the surfaces of raw castings were cleaned with dry compressed air, checked for mechanical damages and marked in places where surface reconstruction procedures were to be carried out.

All surface reconstruction procedures were carried out at the same magnification, allowing the elementary segment length $\mathrm{lr}=239.63 \mu \mathrm{m}$ or its tenfold value $(2396.25 \mu \mathrm{m})$ to be maintained and the electron beam source to be equal to $15 \mathrm{kV}$, thus ensuring accurate observation and recording of the surface details in cast iron samples.

In the measurements of surface roughness, the following parameters were used:

- $\mathrm{SRa}$ - arithmetic mean of absolute values,

- $\mathrm{SRq}$ - root mean square of values,

- SRz - ten highest peaks and lowest valleys over the entire sampling length,

- SRp - maximum peak height,

- SRv - maximum valley depth,

- SRIr - profile length coefficient,

- SRSm - mean width of the roughness profile elements.

An analysis of the accuracy of the measured roughness was performed and compared with notched profile template [Pałyga et al. 2015; Grzesik 2015].

Moulds for the evaluation of external casting surface quality were made from the sand mixtures with the above-mentioned binders and were 


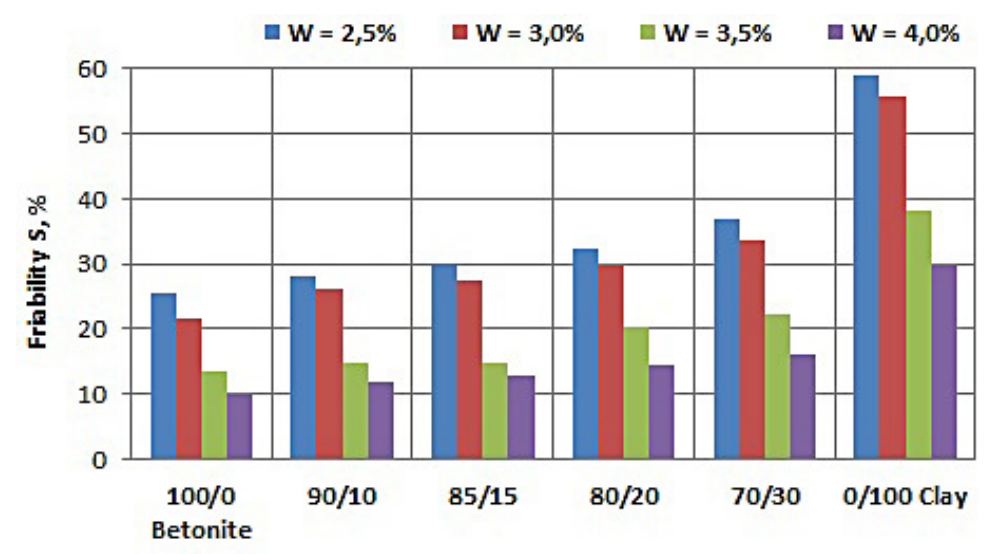

Percentage of bentonite and clay in moulding sand

Fig. 4. The effect of clay content on the friability $\mathrm{S}$ of the tested sand mixtures

poured with cast iron at a temperature of $1390^{\circ} \mathrm{C}$. The obtained stepped castings were sandblasted and subjected to roughness tests.

Table 2 summarizes the results obtained for the tested roughness parameters. Figures 5-10 show section measurements of roughness together with their transverse 2D profile.
In the studied range of values, raising the clay content in the sand mixture had no greater effect on the surface quality of castings. Higher roughness was observed only in the casting made in the moulding sand based on bentonite clay, as further confirmed by the results of friability tests carried out on this sand mixture.

Table 2. The results of testing the selected roughness parameters

\begin{tabular}{|c|c|c|c|c|c|c|}
\hline \multirow{2}{*}{ Parameters } & \multicolumn{6}{|c|}{ Clay content in moulding sand, \% } \\
\cline { 2 - 7 } & $\begin{array}{c}0 \text { (pure } \\
\text { bentonite) }\end{array}$ & $10(90 / 10)$ & $15(85 / 15)$ & $20(80 / 20)$ & $30(70 / 30)$ & $\begin{array}{c}100 \text { (pure } \\
\text { clay) }\end{array}$ \\
\hline SRa, $\mu \mathrm{m}$ & 5.96 & 3.66 & 3.84 & 4.25 & 6.29 & 7.54 \\
\hline SRq, $\mu \mathrm{m}$ & 7.93 & 4.83 & 4.67 & 5.70 & 7.96 & 8.70 \\
\hline SRz, $\mu \mathrm{m}$ & 39.00 & 25.68 & 22.68 & 33.56 & 43.30 & 37.59 \\
\hline SRp, $\mu \mathrm{m}$ & 23.69 & 16.35 & 9.80 & 18.01 & 15.97 & 15.88 \\
\hline SRv, $\mu \mathrm{m}$ & 15.31 & 9.34 & 12.87 & 15.55 & 27.33 & 21.71 \\
\hline SRIr, $\mu \mathrm{m}$ & 107.31 & 105.45 & 106.71 & 105.92 & 105.84 & 106.69 \\
\hline SRSm, $\mu \mathrm{m}$ & 82.36 & 54.04 & 83.24 & 69.28 & 134.20 & 135.17 \\
\hline
\end{tabular}

a)

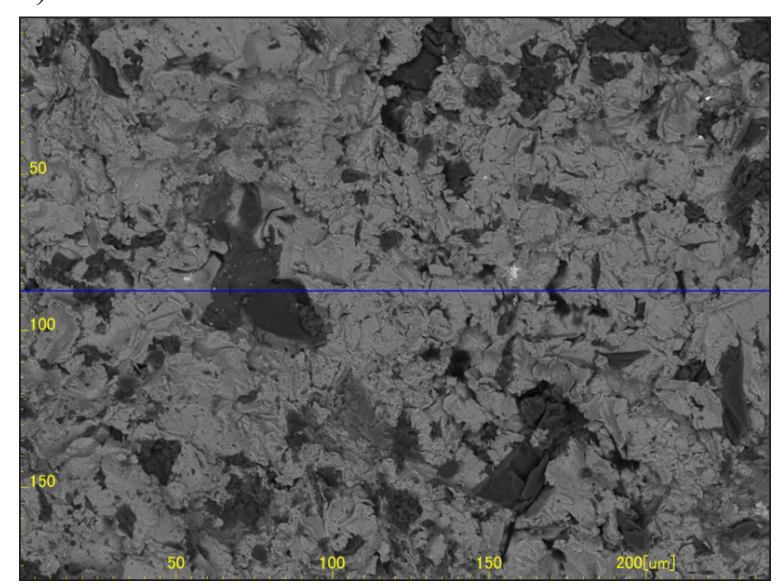

b)

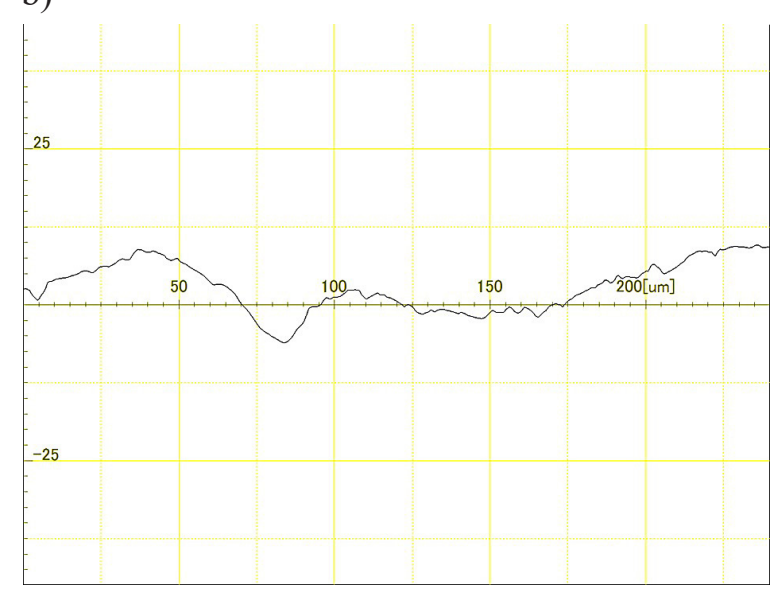

Fig. 5. Bentonite: a) the examined casting surface, b) the transverse profile of the surface 
a)

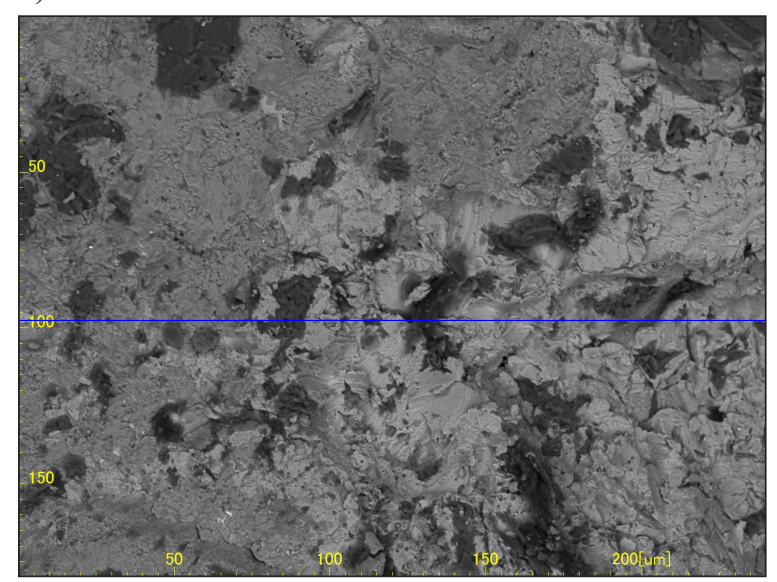

b)

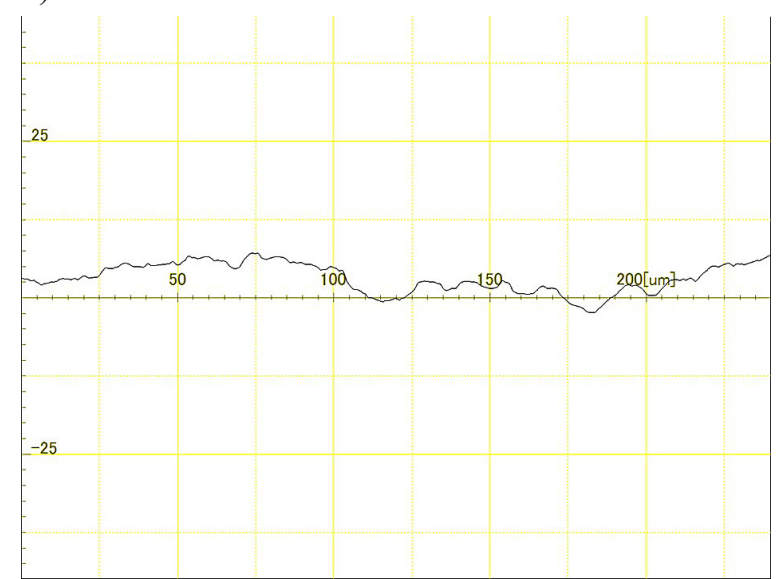

Fig. 6. Hybrid bentonite 90/10: a) the examined casting surface, b) the transverse profile of the surface

a)

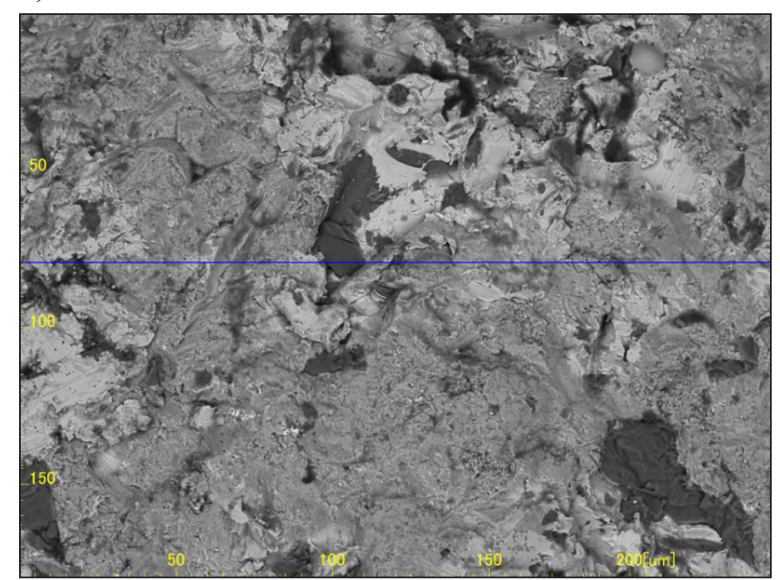

b)

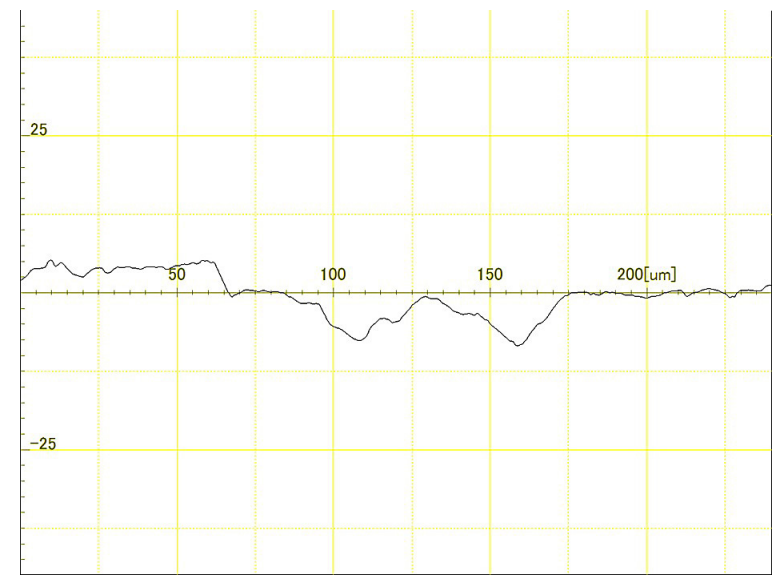

Fig. 7. Hybrid bentonite 85/15: a) the examined casting surface, b) the transverse profile of the surface

a)

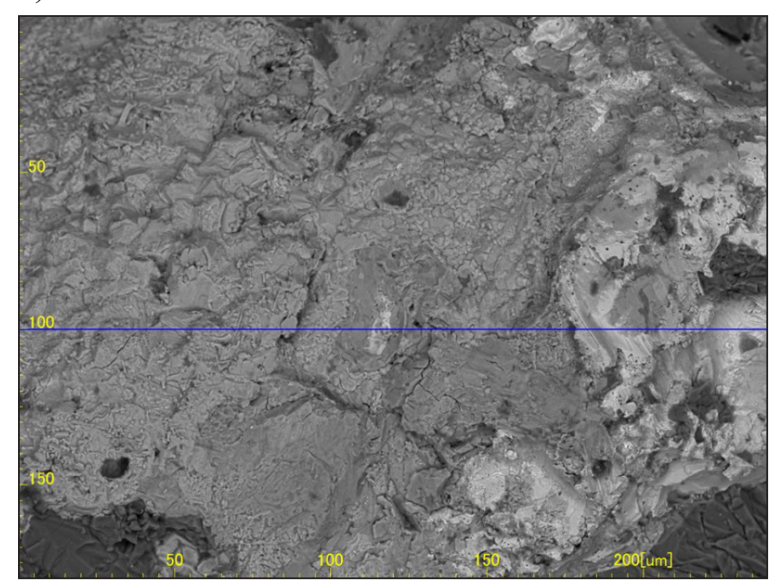

b)

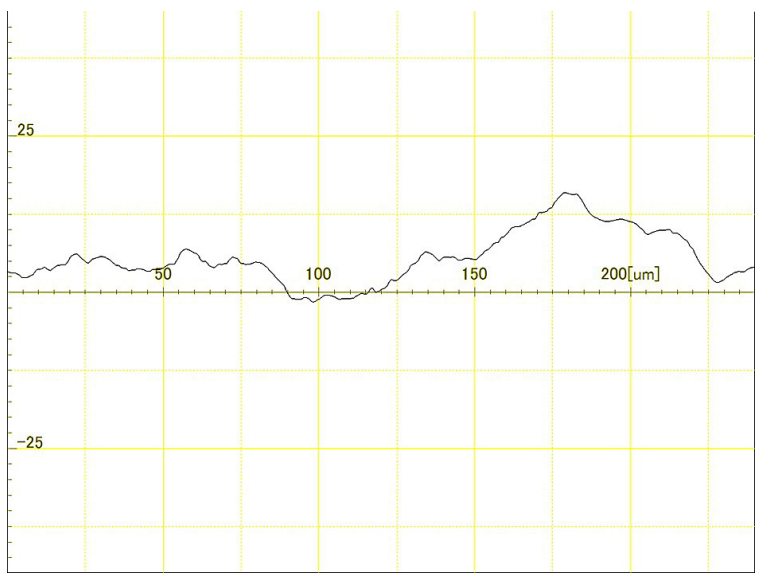

Fig. 8. Hybrid bentonite 80/20: a) the examined casting surface, b) the transverse profile of the surface 
a)

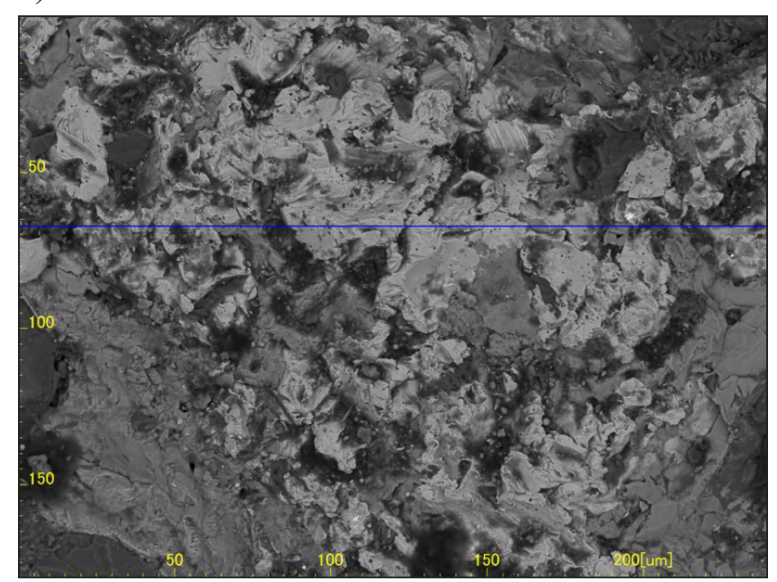

b)

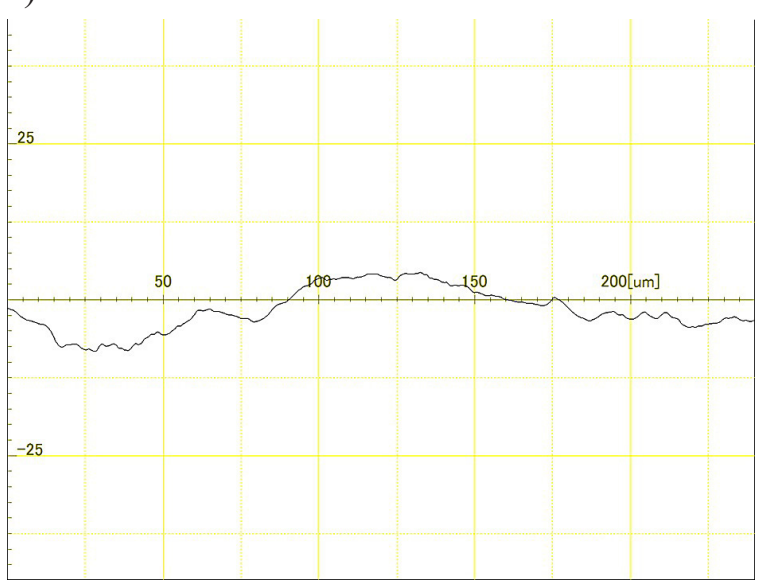

Fig. 9. Hybrid bentonite 70/30: a) the examined casting surface, b) the transverse profile of the surface

a)

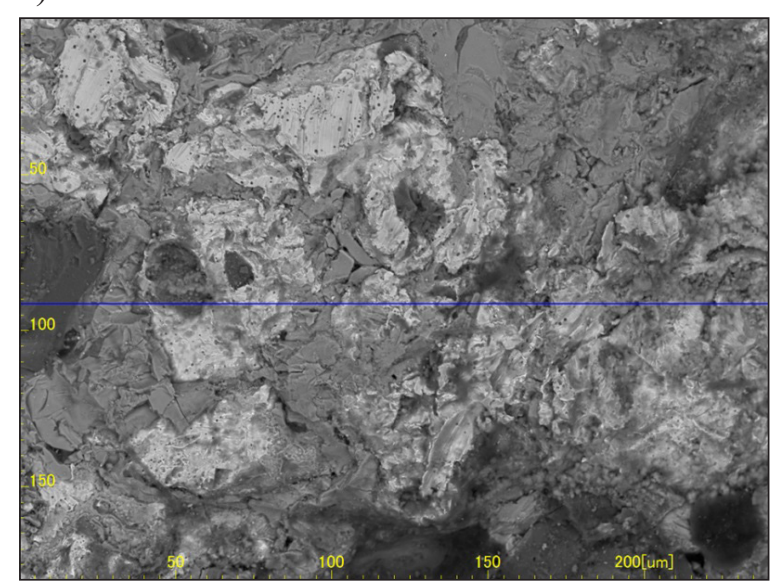

b)

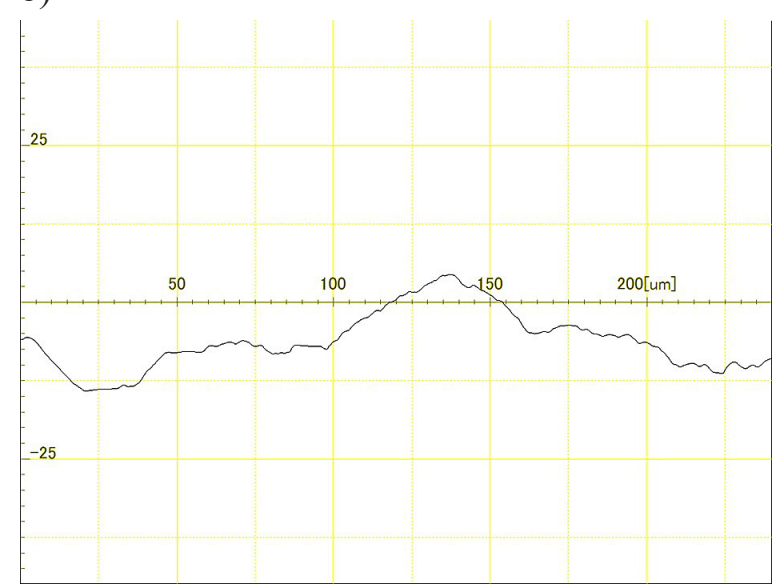

Fig. 10. Bentonite clay: a) the examined casting surface, b) the transverse profile of the surface

\section{CONCLUSIONS}

The research allowed drawing the following conclusions:

1. Compared to clay, foundry bentonite has a much higher content of montmorillonite and greater swelling capacity. Increasing the amount of clay in hybrid bentonites causes gradual decrease in both montmorillonite content and swelling index.

2. Sand mixtures based on hybrid bentonites are characterized by satisfactory technological and mechanical properties, equivalent, and in some cases superior even (90/10 hybrid bentonite), to sands based on pure bentonite.

3. Examining the results of surface roughness measurements in iron castings, it was found that standard scanning electron microscope, used primarily for microscopic observations of sample surfaces, was also applicable in the analysis of surface quality, using image compensation functions on captured images.

4. The results of casting roughness tests show that higher clay content in bentonite has no adverse effect on the external casting surface quality.

5. The obtained results confirm that it is possible to conduct successful exploitation of some of the domestic bentonite clay deposits and produce full-value clay binders for the foundry industry.

\section{Acknowledgements}

The article was prepared as part of the project No. LIDER/21/0125/L-8/16/NCBR/2017. 


\section{REFERENCES}

1. Aramide F.O., Aribo S., Folorunso D.O., 2011. Optimizing the moulding properties of recycled ilaro silica sand. Leonardo Journal of Sciences, 19, 93-102.

2. Beňo J., Lichý P., Kroupová I., Radovský F., 2016. Influencing of foundry bentonite mixtures by binder activation. Metalurgija, 55 (1), 7-10.

3. Brzeziński D., 2018. Surowce mineralne Polski. Bentonity i iły bentonitowe. Retrieved April 2018, from http:/geoportal.pgi.gov.pl/surowce/skalne/ bentonity $/ 2018$

4. Dańko J., Holtzer M., 2010. Metody ograniczenia odpadów z procesów odlewniczych oraz sposoby ich zagospodarowania. Wydawnictwo Naukowe Akapit, Kraków (in Polish).

5. Grzesik W., 2015. Wpływ topografii powierzchni na właściwości eksploatacyjne części maszyn. Mechanik, 8-9, 587-593 (in Polish).

6. Kowalski J.S., 2011. Technologiczne aspekty przemian temperaturowych kwarcowej osnowy piaskowej syntetycznej masy formierskiej z bentonitem. Wydawnictwo Politechniki Krakowskiej, Kraków (in Polish).

7. Lee T., Benson C.H., Eykholt G.R., 2004. Waste green sands as reactive media for groundwater contaminated with trichloroethylene (TCE). Journal of Hazardous Materials, B109, 25-36.

8. Miksovsky F., Lichy P., 2008. The oolitization rate determination of bentonite moulding mixtures. Archives of Foundry Engineering, 8 (2), 103-106.

9. PałygaŁ.,StachowiczM.,GranatK.,2015.Evaluation of $2 \mathrm{D}$ and 3D surface roughness of die castings from alloy A1Si9Cu3. Archives of Foundry Engineering, 15 (1), 75-80.

10. Priyadharsini S., Karunakaran P., 2016. Determination of the physical properties of sand moulding bonded with composite of ipomoea batatas and bentonite with casting application. International Research Journal of Engineering and Technology, 3 (4), 2913-2919.

11. Stefański Z., Warmuzek M., Boroń Ł., 2010. Development of technology to manufacture ,modified bentonite" used in production of steel castings with special regard to casting surface quality. The Transactions of the Foundry Research Institute, L (2), 15-36.

12. Vasková I., Fecko D., Malik J., 2012. The dependence of castings quality produced in clay moulding mixtures from the properties of binder based on a montmorillonite. Archives of Foundry Engineering, 12 (1), 123-128. 